Int. J. Dev. Biol. 61: 683-688 (2017)

doi: $10.1387 / \mathrm{ijdb} .170196 \mathrm{nh}$

\title{
The long and winding path to understanding kidney structure in amphioxus - a review
}

\author{
NICHOLAS D. HOLLAND* \\ Marine Biology Research Division, Scripps Institution of Oceanography, University of California at San Diego,
} La Jolla, California, USA

\begin{abstract}
The history of studies on amphioxus kidney morphology is reviewed with special attention to four zoologists who made important early contributions. In 1884, Hatschek described a single anterior nephridial tubule in larval and adult amphioxus. Subsequently, in 1890, Weiss and Boveri independently found multiple branchial nephridia (morphologically similar to Hatschek's nephridium) associated with the pharyngeal gill slits. These initial discoveries set the stage for Goodrich to criticize Boveri repeatedly for the latter's contention that amphioxus nephridia develop from mesoderm and are connected to neighboring coeloms throughout the life history. In the end, Boveri was almost certainly correct about amphioxus nephridia developing from mesoderm and at least partly right about the lumen of the nephridial tubules being connected to nearby coelomsthe openings are present during larval stages but are closed off later in development. The more detailed structure of amphioxus nephridial tubules was ultimately revealed by electron microscopy. The tubule epithelium includes specialized excretory cells (cyrtopodocytes), each characterized by a basal region similar to that of a vertebrate renal podocyte and an apical region bearing a flagellar/ microvillar process reminiscent of an invertebrate protonephridium. At present, in spite of considerable progress toward understanding the development and structure of amphioxus nephridia, virtually nothing is yet known about how they function, and no consensus has been reached about their phylogenetic significance.
\end{abstract}

KEY WORDS: cephalochordata, amphioxus, lancelet, kidney, evolution

Initially suggested amphioxus kidneys did not stand the test of time

Nineteenth century biologists considered amphioxus to be a vertebrate. They evidently thought that no respectable vertebrate should be without a kidney, so the search began. The locations of the first three suggested kidneys in the amphioxus body are diagrammed in Fig. 1. All were wide of the mark. Müller (1841) ascribed an excretory function to thickened tracts of atrial epithelium. These later became known as glandular strips, suggested by Ruppert (1997) to be sensory. Subsequently, Owen (1866) claimed to have discovered a supra-intestinal renal organ, but nobody else could ever find it again. A third possibility was suggested by E. Ray Lankester, who appears several times in this review as a grey eminence, influencing early research on amphioxus kidneys from behind the scenes. In 1875, Lankester proposed an excretory function for what he initially called pigmented canals (later changing their name to atrio-coelomic funnels). These are two evaginations from the wall of the atrial cavity that, in spite of their name, turned out not to be connected to the coelom and were later proposed to be chemosensory (Holmes, 1953).

\section{Berthold Hatschek and his discovery of a bona fide kidney in amphioxus}

Hatschek (Fig. 2) was born into a prominent Jewish family in Austrian Moravia (now the eastern region of the Czech Republic). A sympathetic account of his life was published by Storch (1950). Hatschek, who was an embryologist and evolutionary biologist, earned his doctorate in Germany and held professorships in Prague and Vienna. He is best remembered for (1) breaking up a supertaxon that had lumped sponges, ctenophores and cnidarians, (2) proposing his trochozoon theory, an evolutionary scenario tracing all bilaterally symmetrical animals back to an ancestor that looked rather like a larval rotifer, and (3) describing the embryology of several invertebrates, including amphioxus (Hatschek, 1893).

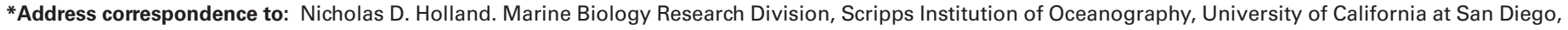
La Jolla, California, USA e-mail: nholland@ucsd.edu
} 


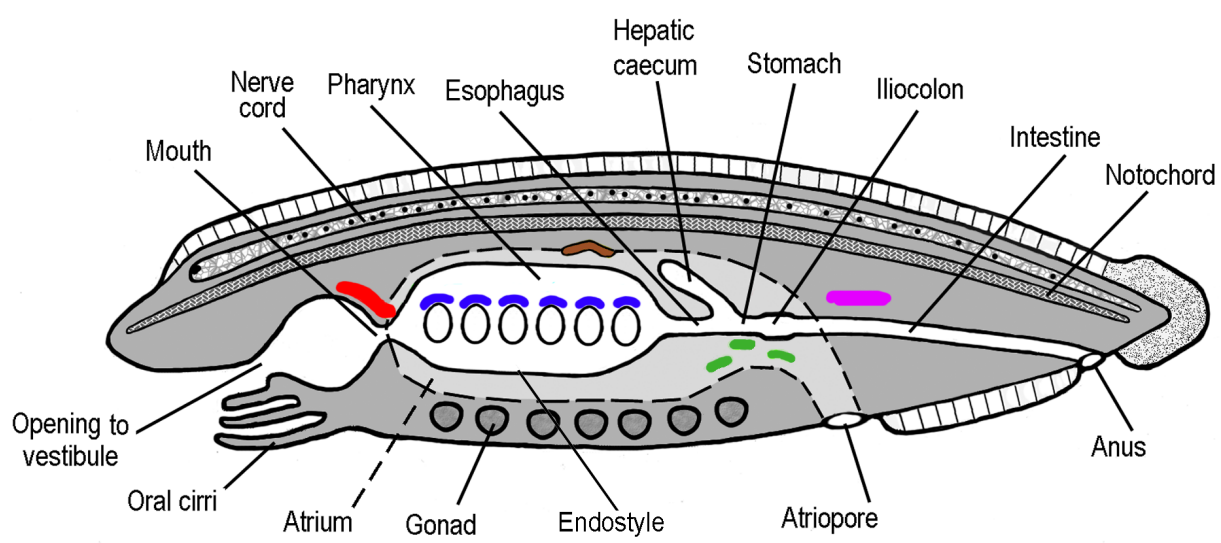

Nephridia that have been suggested but not accepted

$\square$ Glandular strips (Müller, 1841)

$\square$ Supra-intestinal kidney (Owen, 1866)

$\square$ Pigmented canals = Atrio-coelomic funnels (Lankester, 1875, 1889)

Spongy organ (vaguely described, so not shown) (Goldschmidt, 1906)

\section{Accepted nephridia}

Hatschek's nephridium (1884)

Branchial nephridia of Weiss-Boveri (1890)

Fig. 1. Amphioxus structures previously identified as nephridia. The figure represents an adult amphioxus in left-side view and is highly diagrammatic.

He published regularly until 1911 when his research productivity plummeted due to sustained severe depression, although he continued to teach. When the Nazis came to power in Austria, they took away first his job and then his home; he died in poverty in a pension shortly thereafter at age 87.

In 1884, Hatschek found what he proposed (in the event, correctly) was a nephridium near the mouth of larval and adult amphioxus. He briefly characterized it as a coelomic tubule of mesoderm originating from the left first somite. In addition, he surmised that the tubule discharged posteriorly into the pharyngeal lumen. Initially Hatschek was ignored-in doing so, Weiss and Boveri (discussed below) unfairly took credit for pioneering the discovery of excretory organs in amphioxus. Ultimately, Lankester

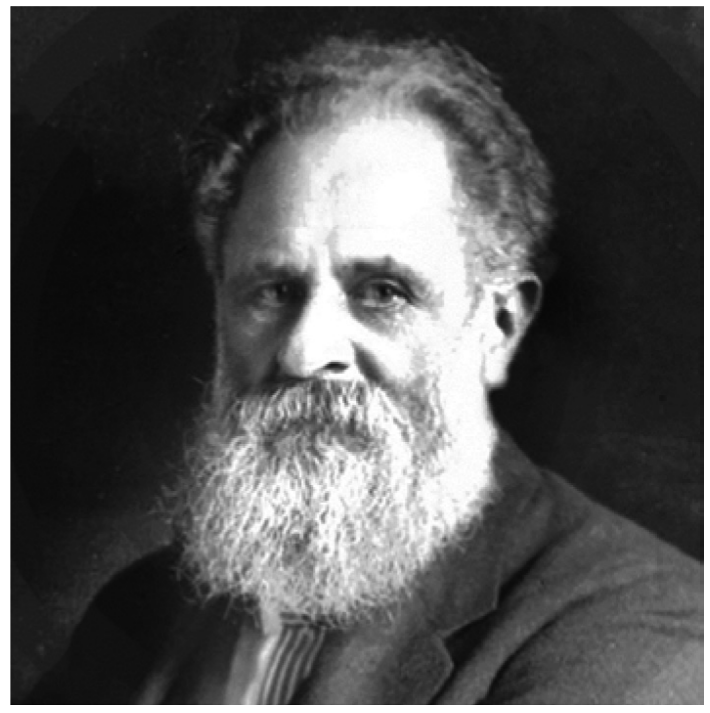

Fig. 2. Berthold Hatschek (1854-1941).
(1891) overcame his initial doubts and accepted Hatschek's tubule as a kidney, and, by 1896, MacBride had coined the still-used name of "Hatschek's nephridium" for the organ. To avoid confusion, one should be aware "Hatschek" is also prefixed to several other structures in amphioxus (a left and a right gut diverticulum, a groove, and a pit).

Frederick Weiss and Theodor Boveri find a second set of kidneys in amphioxus

In 1890, Weiss and Boveri (Fig. 3 A,B), in separate studies, described a second set of kidneys in adult amphioxus. These are the branchial nephridia (sometimes called paired nephridia) associated with and opening into the dorsal edge of each gill cleft along the left and right sides of the pharynx. With further work it became clear that the two different sets of kidneys in amphioxus closely resemble one another morphologically. In the following sections, unless otherwise noted, "nephridium" can be interpreted as applying to both sets of kidneys in amphioxus.

\section{The mystery surrounding the discovery of the branchial nephridia}

Weiss and Boveri contemporaneously discovered the branchial nephridia of amphioxus under mysterious circumstances. For seven weeks in 1889, these two biologists worked simultaneously at Anton Dohrn's Zoological Station in Naples, Italy, on the same problem in the same organism. The next year, when they published substantially overlapping results, neither mentioned the other. In this section, biographical information about Weiss and Boveri has been taken, respectively, from Thomas (1953) and from Baltzer (1967), unless otherwise noted.

Weiss was an Englishman who spent much of his early life in Germany but returned to England for his university education under the guidance of Lankester. When he arrived, his mentor was still denying that Hatschek's tubule was a kidney and was no longer convinced that atrio-coelomic funnels functioned for excretion (Lankester, 1889; Lankester and Willey, 1890). Consequently, Lankester sent the 23-year-old Weiss to Naples for the express purpose of finding more likely excretory organs in amphioxus. During his stay at the Zoological Station (December 30, 1888 to May 2, 1889), Weiss discovered branchial nephridia in vitally stained amphioxus and then described their detailed structure in histological sections. He submitted his results to Quart J Micros Sci in the spring of 1890, and they were published there in the fall of the same year (Weiss, 1890). After his one contribution on amphioxus kidneys, he never wrote another word on the subject-instead he took up botany and eventually became a professor in Owens College (Manchester). His studies of Carboniferous fossil plants earned him election to the Royal Society, and, when he died at a ripe age in 1953, his colleagues remembered him as tactful, friendly and modest.

Boveri was a German with wide international contacts, including 
eventually an American wife. As a 26-year-old postdoctoral fellow qualified for teaching, he visited Naples in 1889 from March 8 to April 24. One of his purposes was to continue research on sea urchin embryology that he had started there the year before, but exceptionally stormy weather during his 1889 visit meant relatively few urchins could be collected. That year Boveri also recorded his annoyance that the other visiting biologists at the Zoological Station were, without exception, an "unattractive" lot. The second purpose of Boveri's 1889 research in Naples, as he explained it a year later (Boveri, 1890), was to follow up his insight that amphioxus should have kidneys by searching for such organs. After demonstrating the branchial nephridia in amphioxus, he returned to Germany where he published his findings in the summer of 1890.

It is extremely unlikely that any documentary evidence will ever come to light about the relations between Weiss and Boveri in Naples well over a century ago. Even so, one is tempted to speculate on what might have happened. In his 1890 paper, Weiss states that, for adult amphioxus, he could not demonstrate that the branchial nephridia "have any internal opening to the coelom, a point of very great interest." If Weiss had discussed his findings with Boveri during their overlapping visits to Naples in 1889, the latter might have questioned the absence of such openings and sought to find them by preparing his own histological sections. Had Boveri done so and seen what he thought were the openings, the two biologists could have resolved their conflict by agreeing to disagree and publish their results separately.

In 1892, Boveri belatedly mentioned that Weiss had done similar work on amphioxus kidneys, but added that it was of low quality and inadequately illustrated. Boveri was also at pains to point out that he had been the first to publish on the subject. This surprisingly abrupt treatment of Weiss appears to fit with one side of Boveri's character, which reputedly could sometimes be "vehement, inflexible, and relentless" (Weinberg, 2008). Once Weiss returned to England, he and Lankester presumably discussed what had happened in Naples, but nothing of that was ever made public. By then, Boveri's disparaging comments and claim to priority would have mattered little to Weiss, who was already in the process of changing his field of research from zoology to botany.

\section{Enter Edwin Goodrich}

The next major player in amphioxus kidney research was Goodrich (Fig. 3C). Soon after entering Oxford University in 1891, he became an assistant to Lankester, the Linacre professor of zoology there. One can rather well imagine that Lankester's long interest in kidneys had something to do with Goodrich's choice of a subject for his undergraduate thesis, which was entitled "On the Coelom, Genital Ducts and Nephridia" and published as a journal article in 1895. In that work, he proposed that several major categories of kidneys occur in invertebrates: namely, close-ended protonephridia and open-ended metanephridia (both ectodermally-derived) as well as mesodermal gonoducts that partly function for excretion. In contrast, he believed that only this last category of kidney characterized vertebrates. In his 1895 paper, Goodrich was hesitant to accept the excretory nature of what his predecessors had called kidneys in amphioxus. However, during the next few years, which included a couple of visits to Italy to study amphioxus, he became convinced that its excretory organs "were in all essentials identical" to the protonephridia of annelid worms" (Goodrich, 1902). Considered from this point of view, the amphioxus kidney should originate from ectoderm and lack connections with adjacent coeloms at any time in the life history. In time, Goodrich himself became the Linacre professor at Oxford, a prestigious position he held throughout the interwar period of the twentieth century while he vigorously promoted his ideas about amphioxus kidneys.

\section{Goodrich/Boveri controversy over nephridial connections to coeloms}

Unlike Goodrich, Boveri (1890) began his kidney studies convinced that all animal excretory organs were homologous and that nephridial tubules commonly remained in connection with adjacent coelomic cavities. Boveri's contention that amphioxus kidneys were permanently connected to the adjacent coelom was opposed, at first tentatively by Weiss (1890) and later forcefully by Goodrich (1902, 1909, 1934a, 1934b). In the end, neither Boveri nor Goodrich was completely right or completely wrong. Amphioxus nephridia
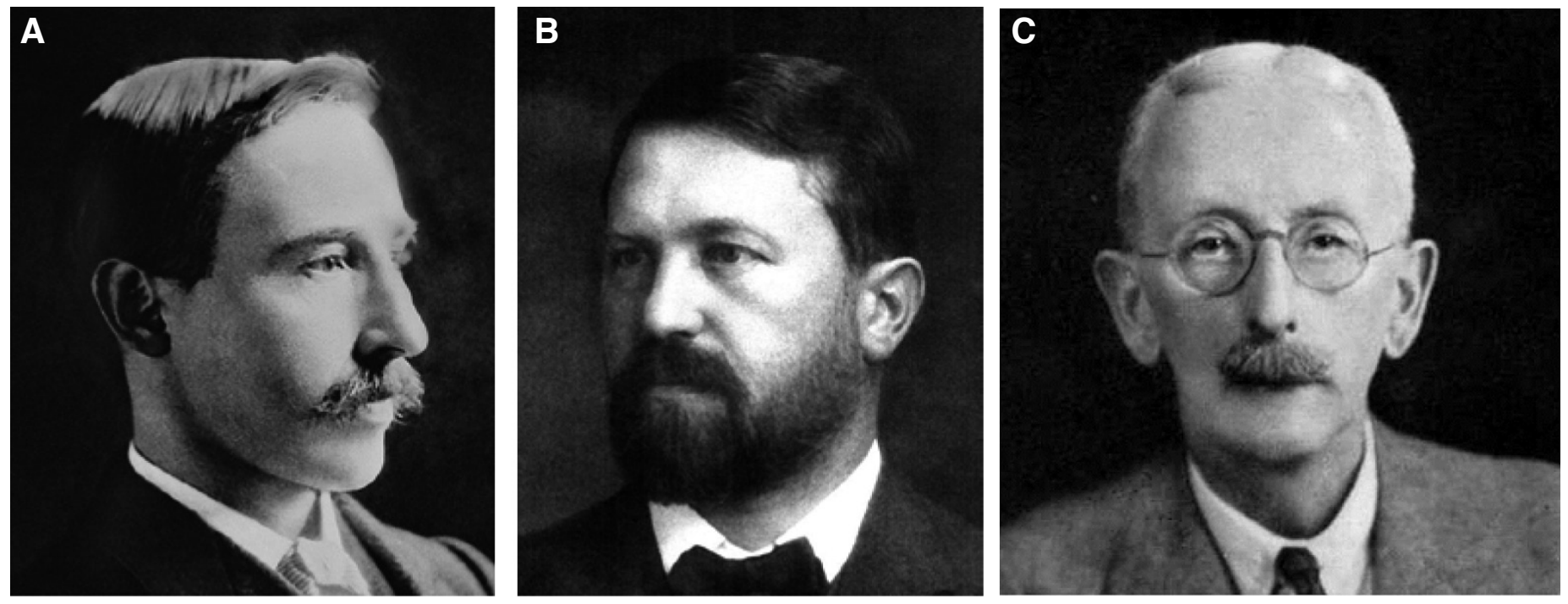

Fig. 3. (A) Frederick E. Weiss (1866-1953), (B) Theodor Boveri (1862-1915) and (C) Edwin S. Goodrich (1868-1946). 
do open to adjacent coeloms during early development (Hatschek, 1884; Naef, 1939), but the connections close later in the life history (Legros, 1909, 1910).

\section{Widespread controversy over the germ layer origin of amphioxus kidneys}

Even though Hatschek (1884), Weiss (1890) and Boveri (1890) were all convinced that amphioxus nephridia had a mesodermal origin, many years of controversy were to intervene before that conclusion was finally widely accepted. For example, an endodermal source was proposed by van Wijhe $(1893,1902)$, while an ectodermal source was favored by Legros (1898) and by Smith and Newth (1917). In 1910, Legros added to the confusion by changing his mind and favoring a mesodermal origin.

From then on, the most persistent advocate for development of the amphioxus kidney from mesoderm was Boveri (1890, 1892, 1904). His position was welcome to those biologists who considered amphioxus to be sort of a vertebrate-in-waiting, possessing kidneys homologous to the vertebrate pronephros.

In opposition to Boveri, Goodrich, as already mentioned, was convinced that amphioxus kidneys should be homologous to the ectodermally-derived protonephridia known from larvae and adults of several invertebrate phyla. In fact, Goodrich (1917, 1934a) was so anxious to endow Hatschek's nephridium with an ectodermal pedigree that that he proposed that the organ developed (from posterior to anterior as it were) from a little group of ectoderm cells in the vicinity of the mouth primordium. Although it is likely that mouth penetration seems to involve (at least in part) a localized ingrowth of ectoderm cells toward the pharyngeal endoderm (my unpublished observations), by that stage of development, the rudiment Hatschek's nephridium is already differentiating from mesoderm more dorsally in the body. Although cell tracer experiments would be necessary to conclusively test the possibility that ectoderm cells are added to the developing Hatschek's nephridium, such an addition appears unlikely.

In the end, therefore, Boveri was very likely correct about the mesodermal origin of amphioxus kidney. Even so, Goodrich continued to advocate an ectodermal origin so forcefully and so repetitiously that it was incorporated uncritically into almost all twentieth century textbooks on comparative anatomy (e.g. Smith, 1953). It is only in recent decades that students of amphioxus have preferred Boveri's conception of a mesodermal origin for the amphioxus kidney (e.g. Stach and Eisler, 1998; Stach, 2000; Kaji et al., 2016), although many secondary sources continue to repeat Goodrich's idea that amphioxus has ectodermal protonephridia (Brusca et al., 2016; Mahasen, 2016).

\section{Slow improvement in understanding the cellular structure of the kidneys}

An accurate conception of the more detailed cellular structure of amphioxus kidneys was slow to develop. A distinctive cell type in the kidney was discovered by Boveri $(1890,1892)$, who called it the thread cell (Fadenzell in the original German) although he erred in thinking the thread was solid and perhaps muscular in nature. Goodrich (1902) improved this description to some extent by claiming that the thread was actually a delicate tube with a flagellum running within it. This arrangement reminded him of the solenocytes (literally, channel cells) described previously in protonephridia of larvae and adults in several groups of invertebrates. He accordingly changed the name of thread cell to solenocyte. The next advance came when Kümmel and Brandenberg (1961) used transmission electron microscopy to show that the tube described by Goodrich on the apical surface of the cell is really a palisade of ten evenlyspaced microvilli surrounding a central flagellum. Kümmel and Brandenberg (1961) also demonstrated that same cell type had an expanded basal region differentiated into an apparatus reminiscent of the fenestrated filtering surface of a vertebrate podocyte. Because of the dual nature of this amphioxus cell type, the name changed yet again - to cyrtopodocyte. "Cyrto" is derived from the Greek for fishing creel, which is suggested by the palisade of long microvilli alternating with slots.

\section{Contemporary confusion about kidney histology in adult amphioxus}

An additional difficulty in understanding amphioxus kidneysboth the branchial nephridia and those of Hatschek-has arisen over their histological structure in adult animals. During the larval stages, amphioxus kidneys are readily understandable as tubules with a component of cyrtopodocytes in their wall. After metamorphosis, however, the organs give the impression of comprising two tubular tissue layers, one within the other. The major part of each cyrtopodocyte is located in the outer layer, and communication with the inner layer is only via the apical flagellar/microvillar process, the tip of which intrudes between adjacent inner layer cells (Welsch, 1975; Tsujii, 1980). The voluminous spaces seeming to separate the outer layer from the inner one have been variously (and vaguely) designated as a kind of coelom (separate from the one constituting the lumen of the inner layer) (Goodrich, 1902, 1909, 1934b; Tsujii, 1980), or as solenocyte chambers (Franz, 1927), or as urinary capsules (Ruppert, 1996). Confusion over the histology would probably disappear if the inner and outer layers of the organ were considered components of one and the same epithelium (as suggested by Nakao, 1965) in which large intercellular spaces are present. Good examples of similarly voluminous spaces within an epithelial layer are not common, but they are conspicuous within the inner ear epithelium of mammals (Sato et al., 1999), specifically as the tunnel of Corti, the space of Nuel, and the spaces separating the Deiters cells from the outer hair cells.

\section{Amphioxus nephridial structure is now well understood-but what about functions?}

The answer to the question above is that virtually nothing is known about nephridial function in amphioxus. It would be hard to construct an animal more unfavorable for studies of excretion. The nephridia are much too small to cannulate, and the volumes of coelomic and haemal fluids are too miniscule for reliable introduction of sensors or tracers. To date, there have been speculations on filtration and mechanics of flow in the nephridia, but no data. Brandenburg and Kümmel (1961) suggested that pressure was higher in neighboring haemal channels than in the lumen of the nephridium and thus drove material through the pores in the basal regions of the cyrtopodocytes. It has also been proposed that the movement of fluids through spaces within the amphioxus kidney might be influenced by muscular contractions, either by the myo- 
epithelial cells adjacent to the cyrtopodocytes (Tyson and Bulger, 1978) and/or by some of the mouth-associated peritoneal muscles inserting on the nephridium (my unpublished observation).

Previous work (Moller and Ellis, 1974; Binyon, 1981; Cuoghi et al., 2016) indicates that amphioxus nephridia are not involved in osmoregulation. However, there is no information about possible excretion (for instance, of nitrogenous waste). Although not concerned with nephridia, Schmitz et al., (2000) studied respiration in amphioxus and obtained results that raise an interesting question about excretory function. They found that diffusion suffices for all the needed gas exchange in the tissues, even in the absence of respiratory water flowing through the pharynx. In the light of such a result, one can wonder why diffusion from amphioxus tissues would not also remove waste products effectively. In other words, why should such a sophisticated nephridium be needed at all? One explanation might be that amphioxus nephridia are vestiges from a time when the ancestors of today's cephalochordates were more bulky and required efficient kidneys to eliminate their excretory products. At any rate, questions about excretory function in amphioxus remain open and await the development of more incisive methods for studying the phenomenon at the tissue and cell level in vivo.

\section{Possible homologies between amphioxus kidneys and those of other animals}

In spite of progress in understanding the development and morphology of amphioxus kidneys, questions remain about their homologies with excretory organs in other animals. This problem has been looked at from several points of view. Amphioxus nephridia have been compared (1) to kidneys of vertebrates in one direction and to those of invertebrates in the other (the initial position of Boveri, 1890; Felix, 1890; Ruppert, 1997), (2) exclusively to kidneys of vertebrates (the later position of Boveri, 1892, 1904), or (3) exclusively to invertebrate protonephridia (Goodrich, 1902, $1909,1917,1934 a, 1934 b)$. A fourth viewpoint is that amphioxus nephridia are probably evolutionary novelties (Goodrich, 1945, was beginning to consider this possibility; Beklemishev, 1969; Valentine, 2004). These varied opinions still need to be resolved. If it were not for the peculiar structure of the cyrtopodocytes, homologies between amphioxus kidneys and the vertebrate pronephros would be more convincing. However, it is not known whether the cyrtopodocyte's flagellar/microvillar process is an excellent example of convergent evolution or a valuable clue about the deeper phylogenetic roots of amphioxus. Moreover, the structure of the flagellar/microvillar process seems altogether too complicated for merely impelling fluid down the nephridial lumen to the pharyngeal lumen. Perhaps one way forward would be to discover how amphioxus cyrtopococytes really work.

\section{Acknowledgements}

I am deeply indebted to Christiane Groeben, archivist at the Stazione Zoologca di Napoli, for information about the scientific guests working at the institution (when it was the Zoologische Station zu Neapel) during the overlapping visits of Weiss and Boveri. My manuscript was much improved by the critical comments of Linda Holland, Thurston Lacalli, and Ekin Tilic.

\section{References}

BALZER, F. (1967). Theodor Boveri: Life and Work of a Great Biologist 1862-1916. Univ Calif Press, Berkeley, pp. 1-165.
BEKLEMISHEV, W.N. (1969). Principles of Comparative Anatomy of Invertebrates, Vol 2, Organology. Edition 3. Oiver and Boyd, Edinburgh, pp. 1-532.

BINYON, J. (1981). The effects of lowered salinity upon Branchiostoma lanceolatum from the English Channel. J Mar Biol Ass UK 61: 685-698.

BOVERI, T. (1890). Ueber die Niere des Amphioxus. Münch Med Wochensch 37 452-455. [Exactly replicated in Boveri (1890) in Sitz Ges Morphol Physiol Münch 6: 65-77.

BOVERI, T. (1892). Die Nierencanälchen des Amphioxus. Ein Beitrag zur Phylogenie des Urogenitalsystems der Wirbelthiere. Zool Jahrb Abt Anat Ontog 5: 429-510.

BOVERI, T. (1904). Bemerkungen über den Bau der Nierenkanälchen des Amphioxus. Anat Anz 25: 599-604.

BRANDENBURG, J., KÜMMEL, G. (1961). Die Feinstruktur der Solenocyten. J Ultrastruct Res 5: 437-452.

BRUSCA, R.C., MOORE, W., SHUSTER, S.M. (2016). Invertebrates. Third Edition. Sinauer, Sunderland MA, pp. 1-1100.

CUOGHI, I., PEDERZOLI, A., MANDRIOLI, M., MOLA, L. (2016). Molecole coinvolte nella regolazione ionica in due specie di anfiosso provenienti da mari diversi. Att Soc Nat Mat Modena 147: 269-277.

FELIX, W. (1890). Zur Entwicklungsgeschichte der Vorniere des Hühnchens. Anat Anz 5: 526-530.

FRANZ, V. (1927). Morphologie der Akranier. Z Gesamte Anat Abt III 27: 464-692.

GOLDSCHMIDT, R. (1905). Amphioxides. Wissenschaftliche Ergebnisse derdeutschen Tiefsee-Expedition auf dem Dampfer "Valdivia" (1898-1899) 12: 1-90.

GOODRICH, E.S. (1895). On the coelom, genital ducts, and nephridia. Quart J Micros Sci 37: 477-510.

GOODRICH, E.S. (1902). On the structure of the excretory organs of amphioxus (part 1). Quart J Micros Sci 45: 493-501.

GOODRICH, E.S. (1909). On the structure of the excretory organs of amphioxus. Parts 2-4. Quart J Micros Sci 54: 185-205.

GOODRICH, E.S. (1917). "Proboscis pores" in craniate vertebrates, a suggestion concerning the premandibular somites and hypophysis. Quart J Micros Sci 62: 539-553.

GOODRICH, E.S. (1934a). The early development of the nephridia in amphioxus: introduction and part I, Hatschek's nephridium. Quart J Micros Sci 76: 499-510.

GOODRICH, E.S. (1934b). The early development of the nephridia in amphioxus: part II, the paired nephridia. Quart J Micros Sci 76: 655-675.

GOODRICH, E.S. (1945). The study of nephridia and genital ducts since 1895 (continued). Quart J Micros Sci 86: 303-393.

HATSCHEK, B. (1884). Mittheilungen über Amphioxus. Zool Anz 7: 517-520.

HATSCHEK, B. (1893). The Amphioxus and its Development. Swan Sonnenschein, London, pp. 1-181.

HOLMES, W. (1953). The atrial nervous system of amphioxus (Branchiostoma). Quart J Micros Sci 94: 523-535.

KAJI, T., REIMER, J.D., MOROV, A.R., KURATANI, S., YASUI, K. (2016). Amphioxus mouth after dorso-ventral inversion. Zool Lett 2: (2).

KÜMMEL, G., BRANDENBERG, J. (1961). Die Reusengeisselzellen (Cyrtocyten). $Z$ Naturforsch 16b: 692-697. [The same authors published an almost identical paper in 1961 in $J$ Ultrastruct Res 5: 437-452.]

LANKESTER, E.R. (1875). On some new points in the structure of amphioxus, and their bearing on the morphology of Vertebrata. Quart J Micros Sci 15: 257-267.

LANKESTER, E.R. (1889). Contributions to the knowledge of Amphioxus lanceolatus, Yarrell. Quart J Micros Sci 29: 365-408.

LANKESTER, E.R. (1891). Zoological articles contributed to the "Encyclopaedia Britannica." Adam and Charles Black, Edinburgh, pp. 1-183.

LANKESTER, E.R., WILLEY, A. (1890). The development of the atrial chamber of Amphioxus. Quart J Micros Sci 31: 445-466.

LEGROS, R. (1898). Développement de la cavité buccale de l'Amphioxus lanceolatus. Contribution a l'étude de la morphologie de la tête. Deuxième partie. Arch Anat Microsc 2: 1-43.

LEGROS, R. (1909). Sur le développement des fentes branchiales et des canalicules de Weiss-Boveri chez l'amphioxus. Anat Anz 34: 126-151.

LEGROS, R. (1910). Sur quelques points de l'anatomie et du développement de I' amphioxus. Sur le nephridium de Hatschek. Anat Anz 35: 561-587. 


\section{N.D. Holland}

MACBRIDE, E.W. (1896). Note on the formation of the germinal layers in amphioxus. Proc Cambridge Phil Soc 9:150-153.

MAHASEN, L.M.A. (2016). Evolution of the kidney. AnatPhysiolBiochem 1 (1): 555554.

MOLLER, P.C., ELLIS, R.A. (1974). Fine structure of the excretory system of amphioxus (Branchiostoma floridae) and its response to osmotic stress. Cell Tiss Res 148: 1-9.

MÜLLER, J. (1841). Mikroskopische Untersuchungen über den Bau und die Lebenserscheinungen des Branchiostoma lubricum Costa, Amphioxus lanceolatus Yarrell. Bericht Preuss Akad Wiss Berlin 1841: 396-411.

NAEF, A. (1939). Die Entwicklung der Kiementaschen und Nephridien beim larvalen und metamorphosierenden Lanzettfischen. Zool Jahrb Abt Anat Ontog Tiere 65: 469-516.

NAKAO, T. (1965). The excretory organ of Amphioxus (Branchiostoma) belcheri. J Ultrastruct Res 12: 1-12.

OWEN, R. (1866). Anatomy of Vertebrates, Vol 1: Fishes and Reptiles. Longmans Green, London, pp. 1-650.

RUPPERT, E.E. (1996). Morphology of Hatschek's nephridium in larval and juvenile stages of Branchiostoma virginiae (Cephalochordata). Israel J Zool 42 suppl: S161-S182.

RUPPERT, E.E. (1997). Cephalochordata (Acrania). In Microscopic Anatomy of Invertebrates, Vol 15 (Ed. Harrison, F.W., Ruppert, E.E.). Wiley-Liss, New York, pp. 349-504.

SATO, M., LEAKE, P.A., HRADEK, G.T. (1999). Postnatal development of the organ of Corti in cats: a light microscopic morphometric study. Hearing Res 127: 1-13.

SCHMITZ, A., GEMMEL, M., PERRY, S.F. (2000). Morphometric partitioning of respiratory surfaces in amphioxus (Branchiostoma lanceolatum Pallas). J Exp Biol 203: 3381-3390.
SMITH, H.W. (1953). From Fish to Philosopher. Little Brown, Boston, pp.1-264

SMITH, K.M., NEWTH, H.G. (1917). A note concerning the collar cavities of the larval amphioxus. Quart J Micros Sci 62: 243-251.

STACH, T. (2000). Microscopic anatomy of developmental stages of Branchiostoma lanceolatum (Cephalochordata, Chordata). Bonner Zool Monogr 47: 1-111.

STACH, T., EISLER, K. (1998). The ontogeny of the nephridial system of the larval amphioxus (Branchiostoma lanceolatum). Acta Zool Stockh 79: 113-118.

STORCH, O. (1950). Berthold Hatschek. Österreichische Akademie der Wissenschaften. Almanach für das Jahr 1949; 99. Jahrgang. Rohrer, Wien, pp. 284-296.

THOMAS, H.H. (1953). Frederick Ernest Weiss, 1865-1953. Obit Notices Fellows Roy Soc 8: 601-608.

TSUJII, T. (1980). Ultrastructure of the solenocyte in amphioxus, Branchiostoma belcheri (Gray). (In Japanese). Shigei Med J 2: 11-20.

TYSON, G.E., BULGER, R.E. (1978). Coelomic myoepithelial cells of amphioxus and their possible significance in renal function. Trans Amer Micros Soc 97: 397-402.

VALENTINE, J.W. (2004). The Origin of Phyla. Univ Chicago Press, Chicago, pp. 1-608

VAN WIJHE, W.J. (1893). Ueber Amphioxus. Anat Anz 8: 152-172.

VAN WIJHE, W.J. (1902). Beiträge zur Anatomie der Kopfregion des Amphioxus lanceolatus. Petrus Camper, Nederl Bijd Tot Anat 1: 109-194.

WEINBERG, R.A. (2008). In retrospect: the chromosome trail. Nature 453: 725.

WEISS, F.E. (1890). Excretory tubules in Amphioxus lanceolatus. Quart J Micros Sci 31: 489-497.

WELSCH, U. (1975). The fine structure of the pharynx, cyrtopodocytes and digestive caecum of amphioxus (Branchiostoma lanceolatum). Symp Zool Soc Lond 36: 17-41. 


\section{Further Related Reading, published previously in the Int. J. Dev. Biol.}

From the American to the European amphioxus: towards experimental Evo-Devo at the origin of chordates

Jordi Garcia-Fernàndez, Senda Jiménez-Delgado, Juan Pascual-Anaya, Ignacio Maeso, Manuel Irimia, Carolina Minguillón, Ėlia BenitoGutiérrez, Josep Gardenyes, Stéphanie Bertrand and Salvatore D’Aniello

Int. J. Dev. Biol. (2009) 53: 1359-1366

https://doi.org/10.1387/ijdb.072436jg

Evolution of CUT class homeobox genes: insights from the genome of the amphioxus, Branchiostoma floridae Naohito Takatori and Hidetoshi Saiga

Int. J. Dev. Biol. (2008) 52: 969-977

https://doi.org/10.1387/ijdb.072541nt

Peter Holland, homeobox genes and the developmental basis of animal diversity

Sebastian M. Shimeld

Int. J. Dev. Biol. (2008) 52: 3-7

https://doi.org/10.1387/ijdb.072394ss

Developmental expression of the High Mobility Group B gene in the amphioxus, Branchiostoma belcheri tsingtauense

Xiangwei Huang, Lifeng Wang and Hongwei Zhang

Int. J. Dev. Biol. (2005) 49: 49-46

http://www.intjdevbiol.com/web/paper/041915xh

Cell morphology in amphioxus nerve cord may reflect the time course of cell differentiation T C Lacalli

Int. J. Dev. Biol. (2000) 44: 903-906

http://www.intjdevbiol.com/web/paper/11206331

Embryonic development of heads, skeletons and amphioxus: Edwin S. Goodrich revisited P W Holland

Int. J. Dev. Biol. (2000) 44: 29-34

http://www.intjdevbiol.com/web/paper/10761843

Amphioxus Hox genes: insights into evolution and development

$\mathrm{J}$ Garcia-Fernàndez and $\mathrm{P}$ W Holland

Int. J. Dev. Biol. (1996) 40: S71-S72

http://www.intjdevbiol.com/web/paper/9087701

5 yr ISI Impact Factor $(2013)=2.879$
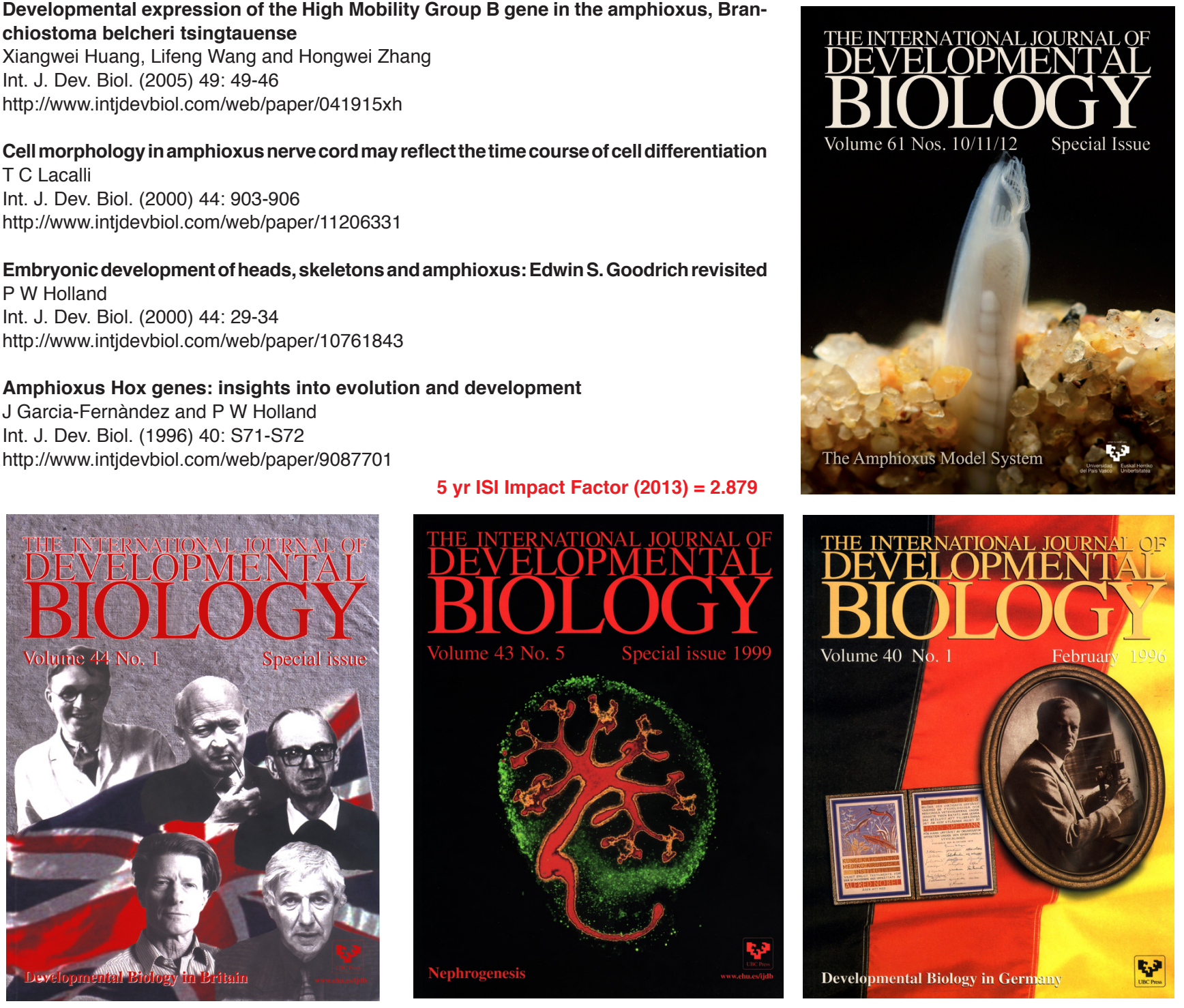